\title{
Repeated Cocaine Administration Increases Voltage-Sensitive Calcium Currents in Response to Membrane Depolarization in Medial Prefrontal Cortex Pyramidal Neurons
}

\author{
Fernando J. Nasif, Xiu-Ti Hu, and Francis J. White \\ Department of Cellular and Molecular Pharmacology, Rosalind Franklin University of Medicine and Science, The Chicago Medical School, North Chicago, \\ Illinois 60064
}

\begin{abstract}
The medial prefrontal cortex (mPFC) plays a critical role in cocaine addiction. However, evidence to elucidate how the mPFC is functionally involved in cocaine addiction remains incomplete. Recent studies have revealed that repeated cocaine administration induces various neuroadaptations in pyramidal mPFC neurons, including a reduction in voltage-gated $\mathrm{K}^{+}$currents (VGKCs) and a possible increase in voltage-sensitive $\mathrm{Ca}^{2+}$ currents $\left(I_{\mathrm{Ca}}\right)$. Here, we performed both current-clamp recordings in brain slices and voltage-clamp recordings in freshly dissociated cells to determine whether $I_{\mathrm{Ca}}$ is altered in $\mathrm{mPFC}$ pyramidal neurons after chronic cocaine treatment with a short-term or long-term withdrawal. In addition, a critical role of VGKCs in regulating the generation of Ca ${ }^{2+}$ plateau potential was also studied in mPFC neurons. Repeated cocaine administration significantly prolonged the duration of evoked Ca ${ }^{2+}$ plateau potentials and increased the whole-cell $I_{\mathrm{Ca}}$ in mPFC neurons after a $3 \mathrm{~d}$ withdrawal. Selective blockade of L-type Ca ${ }^{2+}$ channels by nifedipine not only significantly increased the threshold but also reduced the duration and amplitude of $\mathrm{Ca}^{2+}$ plateau potentials in both saline- and cocaine-withdrawn mPFC neurons. However, there was no significant difference in the increased threshold, reduced duration, and decreased amplitude of $\mathrm{Ca}^{2+}$ potentials between saline- and cocaine-withdrawn neurons after blockade of $\mathrm{L}^{2}$-type $\mathrm{Ca}^{2+}$ channels. Moreover, an increase in amplitude was also observed, whereas the prolonged duration persisted, in $\mathrm{Ca}^{2+}$ potentials after $2-3$ weeks of withdrawal. These findings indicate that chronic exposure to cocaine facilitates the responsiveness of $I_{\mathrm{Ca}}$, particularly via the activated L-type $\mathrm{Ca}^{2+}$ channels, to excitatory stimuli in rat mPFC pyramidal neurons.
\end{abstract}

Key words: cocaine; medial prefrontal cortex; psychostimulant; $\mathrm{Ca}^{2+}$ current; $\mathrm{Ca}^{2+}$ plateau potential; patch clamp

\section{Introduction}

The medial prefrontal cortex (mPFC) is an important structure in the mesocorticolimbic dopamine (DA) system, which is functionally implicated in several neurological disorders, including cocaine addiction (for review, see Tzschentke, 2001). In rodents, lesions of the mPFC abolish neuroadaptations in the mesoaccumbens DA system and prevent increased behavioral responses to cocaine (Li et al., 1999), suggesting that the glutamatergic output from the mPFC plays a critical role in the development of behavioral sensitization, an established model of drug addiction (Pierce et al., 1998; Wolf, 1998). Despite evidence indicating involvement of the mPFC in cocaine addiction, little is known about whether and how chronic exposure to cocaine affects the activity of pyramidal mPFC neurons. Recent investigations reveal

Received Jan. 3, 2005; revised Feb. 15, 2005; accepted March 3, 2005.

This work was supported by United States Public Health Service Grant DA12618 and Senior Scientist Award DA00456 (F.J.W.). We thank Kerstin Ford and Carolyn Grevers for their excellent technical assistance. We also thank Dr. Anthony West for his helpful comments regarding this paper.

Correspondence should be addressed to Dr. Xiu-Ti Hu, Department of Cellular and Molecular Pharmacology, Rosalind Franklin University of Medicine and Science, The Chicago Medical School, 3333 Green Bay Road, North Chicago, IL 60064. E-mail: Xiu-Ti.Hu@rosalindfranklin.edu.

DOI:10.1523/JNEUROSCI.0010-05.2005

Copyright $\odot 2005$ Society for Neuroscience $\quad$ 0270-6474/05/253674-06\$15.00/0 that repeated cocaine administration alters ion channel function in $\mathrm{mPFC}$ neurons, leading to an increase in evoked firing frequency and a decrease in voltage-gated $\mathrm{K}^{+}$currents (VGKCs) in cocaine-withdrawn mPFC neurons (Dong et al., 2005; Nasif et al., 2005).

Neuronal excitability is primarily controlled and regulated by $\mathrm{Na}^{+}, \mathrm{Ca}^{2+}$, and $\mathrm{K}^{+}$channels (Hille, 2001). It is possible that repeated cocaine administration may not only affect VGKCs but also alter the activity of $\mathrm{Ca}^{2+}$ and $\mathrm{Na}^{+}$currents in mPFC neurons. Although it is currently unknown whether $\mathrm{Na}^{+}$channel function is changed after repeated cocaine administration, a possible increase in $I_{\mathrm{Ca}}$ in cocaine-withdrawn mPFC neurons has been suggested (Nasif et al., 2005). It is well established that cortical neurons express various subtypes of $\mathrm{Ca}^{2+}$ channels (Brown et al., 1993; Ye and Akaike, 1993; Lorenzon and Foehring, 1995), which are modulated by DA receptors (Young and Yang, 2004). Based on those findings, we hypothesize that chronic cocaineinduced alterations in DA neurotransmission may change the activity of whole-cell $I_{\mathrm{Ca}}$, thereby increasing the membrane excitability in rat pyramidal mPFC neurons, particularly in response to certain stimuli. The present study was performed to determine whether repeated cocaine administration facilitates $\mathrm{Ca}^{2+}$ channel function in mPFC pyramidal neurons after a short- or longterm withdrawal. 


\section{Materials and Methods}

Animals and pretreatment. Male Sprague Dawley rats ( $\sim 4$ weeks of age) were group housed in a vivarium under a $12 \mathrm{~h}$ light/dark cycle. Food and water were available ad libitum. Rats received repeated administration of saline $(0.1 \mathrm{ml})$ or cocaine $\left(15 \mathrm{mg} \cdot \mathrm{kg}^{-1} \cdot \mathrm{d}^{-1}\right.$, i.p. $)$ for 5 consecutive days, followed by a $3 \mathrm{~d}$ (short-term) or a 2-3 week (long-term) withdrawal. After the pretreatment with saline or cocaine, rats were $\sim 5-6$ weeks of age. In electrophysiological experiments, technical limitations usually restrict voltage-clamp recordings in freshly dissociated neurons from rats $>6$ weeks of age. A prolonged time period for tissue digestion and increased physical force for cell dissociation from older tissues with increased density of fibers could cause damage in dissociated cells that would make the recording extremely difficult. All experimental procedures were in strict accordance with the National Research Council Guide for the Care and Use of Laboratory Animals and were approved by our Institutional Animal Care and Use Committee.

Current-clamp recordings in brain slices. Rats were decapitated under halothane anesthesia, and the brain was immediately excised and immersed in ice-cold artificial CSF (aCSF) containing the following (in $\mathrm{mm}): 124 \mathrm{NaCl}, 2.5 \mathrm{KCl}, 26 \mathrm{NaHCO}_{3}, 2 \mathrm{MgCl}_{2}, 2 \mathrm{CaCl}_{2}$, and 10 glucose, $\mathrm{pH} 7.4(310 \mathrm{mOsm} / \mathrm{l})$. Coronal sections $(300 \mu \mathrm{m})$ containing the $\mathrm{mPFC}$ were sliced and incubated in oxygenated $\left(95 \% \mathrm{O}_{2} / 5 \% \mathrm{CO}_{2}\right)$ aCSF for $1 \mathrm{~h}$ at room temperature before recording. Slices were anchored in a recording chamber and perfused with oxygenated aCSF. All current-clamp recordings in slice preparations were performed at $34^{\circ} \mathrm{C}$. Recording glass pipettes were pulled with a horizontal pipette puller, measured with a resistance of 3-5 $\mathrm{M} \Omega$, and filled with internal recording solution (in $\mathrm{mm}$ ): $120 \mathrm{~K}^{+}$-gluconate, 10 HEPES, 0.1 EGTA, $20 \mathrm{KCl}, 2 \mathrm{MgCl}_{2}, 3$ $\mathrm{Na}_{2} \mathrm{ATP}$, and $0.3 \mathrm{Na}_{2} \mathrm{GTP}$. Long $\mathrm{Ca}^{2+}$ plateau potentials were generated using the following internal solution (in $\mathrm{mm}$ ): $140 \mathrm{Cs}^{+}$-gluconate, 10 HEPES, $2 \mathrm{MgCl}_{2}, 3 \mathrm{Na}_{2} \mathrm{ATP}$, and $0.3 \mathrm{Na}_{2} \mathrm{GTP}$. Recordings were performed in visually identified $\mathrm{mPFC}$ pyramidal neurons within the layers V-VI using differential interference contrast microscopy (Stuart et al., 1993). After whole-cell configuration was formed, voltage-clamp mode was changed to current-clamp recording. The signals were amplified, digitized, and distributed to a computer. $\mathrm{Ca}^{2+}$ plateau potentials were generated with depolarizing current pulses after blockade of $\mathrm{Na}^{+}$and $\mathrm{K}^{+}$channels (Hu et al., 2004). Characteristics of the $\mathrm{Ca}^{2+}$ potential were obtained from the initial spike evoked by the minimal depolarizing current (rheobase) in each $\mathrm{mPFC}$ neuron recorded. After the membrane depolarization caused by internal application of $\mathrm{Cs}^{+}$, mPFC pyramidal neurons with stable resting membrane potential (RMP) were recorded and used for analysis.

Voltage-clamp recordings in freshly dissociated $m P F C$ neurons. The brain tissues were immersed in ice-cold high-sucrose solution (in mM: $25 \mathrm{NaCl}, 2.5 \mathrm{KCl}, 5 \mathrm{HEPES}, 11 \mathrm{D}$-glucose, 210 sucrose, $2 \mathrm{CaCl}_{2}$, and $2 \mathrm{MgSO}_{4}, \mathrm{pH} 7.40$ ) and cut to coronal sections $(350 \mu \mathrm{m})$. As described in our previous study (Zhang et al., 2002), slices were incubated in holding solution, digested with protease (type XIV; $1.5 \mathrm{mg} /$ $\mathrm{ml}$ ), and rinsed with a low $\mathrm{Ca}^{2+}$, HEPESbuffered saline. The tissue was then dissected, and cells were mechanically dissociated with a graded series of fire-polished Pasteur pipettes. The suspension was placed into a Petri dish containing $2 \mathrm{ml}$ of HEPES-buffered HBSS, which was mounted under an inverted microscope. Dissociated cells were allowed to settle, and the solution bathing them was changed to the external solution. Electrodes were pulled from Corning (Corning, NY) 7056 glass capillaries and fire-polished before use. Voltagesensitive $I_{\mathrm{Ca}}$ was isolated by using an internal solution consisting of (in mM) $180 \mathrm{~N}$-methylglutamine, 40 HEPES, $4 \mathrm{MgCl}_{2}$, 0.1 BAPTA, 12 phosphocreatine, $2 \mathrm{Na}_{2} \mathrm{ATP}, 0.2 \mathrm{Na}_{2} \mathrm{GTP}$, and 0.1 leupeptin, pH 7.3 (270-275 mOsm/l) and an external solution consisting of (in $\mathrm{mM}) 135$ $\mathrm{NaCl}, 20 \mathrm{CsCl}, 1 \mathrm{MgCl}_{2}, 10$ glucose, 10 HEPES, 0.001 TTX, and $5 \mathrm{BaCl}_{2}$, pH 7.4 (300-305 $\mathrm{mOsm} / \mathrm{l}) . \mathrm{Ba}^{2+}$ was used as a charge carrier and $\mathrm{K}^{+}$channel blocker (Lorenzon and Foehring, 1995). Recordings were performed using an amplifier and controlled/monitored with a personal computer. After seal rupture, the series resistance $(<10 \quad \mathrm{M} \Omega)$ was compensated $(70-80 \%)$ and periodically monitored. $I_{\mathrm{Ca}}$, with leak subtraction, was activated by stepping the voltage from the holding potential $(-90 \mathrm{mV})$ to various membrane potentials (up to $40 \mathrm{mV}$ ). Voltage-clamp experiments were performed at room temperature $\left(20-22^{\circ} \mathrm{C}\right)$.

Drug application and statistics. During current-clamp recordings, TTX $(1 \mu \mathrm{M})$, tetra-
Figure 1. Characterization of $\mathrm{Ca}^{2+}$ potentials in $\mathrm{MPFC}$ pyramidal neurons. $\boldsymbol{A}$, Representative traces show that $\mathrm{Ca}^{2+}$ spikes, with a short duration but without a stepwise repolarization, were evoked with blockade of $\mathrm{Na}^{+}$channels and TEA-sensitive $\mathrm{K}^{+}$ channels in saline-pretreated neurons (inset indicates extended durations). $\boldsymbol{B}$, With internal $\mathrm{Cs}^{+}$and bath-applied TTX, $\mathrm{Ca}^{2+}$ potentials exhibited a longer duration and apparent stepwise repolarization. C, With application of TTX, TEA, and Cs, typical $\mathrm{Ca}^{2+}$ plateau potentials were evoked. $\boldsymbol{D}$, The plateau potential was blocked by $\mathrm{Cd}^{2+} . \boldsymbol{E}, \boldsymbol{F}$, Bar graphs indicate an increase in the spike duration and amplitude, respectively, with blockade of different $\mathrm{K}^{+}$channels ( ${ }^{*} p<0.05$ compared with TEA plus TTX; ${ }^{\#} p<0.05$ compared with $\left(\mathrm{s}^{+}\right.$plus TTX). 
ethylammonium chloride (TEA) (20 mm), $\mathrm{CdCl}_{2}(200 \mu \mathrm{M})$, and the selective L-type $\mathrm{Ca}^{2+}$ channel blocker nifedipine $(5 \mu \mathrm{M})$ were applied externally in the bath solution. $\mathrm{Cs}^{+}$-gluconate $(140 \mathrm{~mm})$ was applied internally in the cytosol. The glutamate receptor antagonist kynurenic acid $(2.5 \mathrm{~mm})$ and the $\mathrm{GABA}_{\mathrm{A}}$ receptor antagonist 2-(3-carboxypropyl)-3-amino-6-(4-methoxyphenyl)-pyridazinium bromide $(4 \mu \mathrm{M})$ were bath applied in all experiments. Statistical comparisons between cocaine- and saline-pretreated rats were made using either paired and unpaired Student's $t$ tests or two-way ANOVA with repeated measures.

\section{Results}

$\mathrm{Ca}^{2+}$ plateau potentials were initially characterized using current-clamp recordings in $\mathrm{mPFC}$ neurons of saline-pretreated rats (Fig. 1). Because the mean RMP was approximately $-67 \mathrm{mV}$ (Nasif et al., 2005), all mPFC neurons were held at this RMP level during slice recordings. To determine whether $\mathrm{K}^{+}$channels affected the generation of $\mathrm{Ca}^{2+}$ potentials in mPFC neurons, different $\mathrm{K}^{+}$channel blockers were applied externally and/or internally. With the application of TTX and TEA, depolarizing current pulses (0.3-0.55 nA) evoked $\mathrm{Ca}^{2+}$ spikes with a very short duration (Fig. $1 A$ ). With internally applied $\mathrm{Cs}^{+}(140 \mathrm{~mm})$, which blocked both TEAsensitive and TEA-insensitive $\mathrm{K}^{+}$channels, an increased duration in $\mathrm{Ca}^{2+}$ potentials was observed (Fig. $1 B$ ). It was also noted that an apparent stepwise repolarization, with a primary (first) and a smaller secondary membrane depolarization, occurred in $\mathrm{Ca}^{2+}$ potentials. Blockade of $I_{\mathrm{Na}}$ by TTX and VGKCs (internally by $\mathrm{Cs}^{+}$ and externally by TEA) evoked longlasting $\mathrm{Ca}^{2+}$ plateau potentials $(>1.5 \mathrm{sec})$ in saline-withdrawn mPFC neurons (Fig. $1 C)$, indicating that complete blockade of all types of $\mathrm{K}^{+}$channels was required for the development of $\mathrm{Ca}^{2+}$ plateau potentials ( $\mathrm{Hu}$ et al., 2004). $\mathrm{Cd}^{2+}$ eliminated this potential (Fig. 1D). Bar graphs indicate that, with the application of different $\mathrm{K}^{+}$channel blockers (Fig. $1 E, F$ ), there was a significant increase in the durations (TEA plus TTX vs Cs ${ }^{+}$plus TTX, $113.90 \pm$ 8.24 vs $496.47 \pm 102.92 \mathrm{~ms}, n=9$ vs 7 cells, $t=4.574,{ }^{\star} p<0.05$; TEA plus TTX vs $\mathrm{Cs}^{+}$plus TEA plus TTX, $113.90 \pm 8.24$ vs $1867.82 \pm 203.64 \mathrm{~ms}$, $n=9$ vs 10 cells, $t=8.582,{ }^{*} p<0.05 ; \mathrm{Cs}^{+}$plus TTX vs $\mathrm{Cs}^{+}$plus TEA plus TTX, $496.47 \pm 102.92$ vs $1867.82 \pm 203.64 \mathrm{~ms}, n=7$ vs 10 cells, $t=5.573,{ }^{*} p<0.05$ ) (Fig. $1 E$ ) and the amplitudes (TEA plus TTX vs $\mathrm{Cs}^{+}$plus TTX, $36.39 \pm 2.22$ vs $54.57 \pm 2.60 \mathrm{mV}, n=9$ vs 7 cells, $t=$ $5.083,{ }^{*} p<0.05$; TEA plus TTX vs $\mathrm{Cs}^{+}$plus TEA plus TTX, $36.39 \pm$ 2.22 vs $64.20 \pm 1.34 \mathrm{mV}, n=9$ vs $10, t=10.782,{ }^{*} p<0.05 ; \mathrm{Cs}^{+}$plus $\mathrm{TTX}_{\text {vs }} \mathrm{Cs}^{+}$plus TEA plus TTX, $54.57 \pm 2.60 \mathrm{vs} 64.20 \pm 1.34 \mathrm{mV}$, $n=9$ vs 10 cells, $t=3.840,{ }^{*} p<0.05$ ) (Fig. $1 F$ ) of $\mathrm{Ca}^{2+}$ potentials when $\mathrm{K}^{+}$channels were fully blocked. saline; Wash, washout.

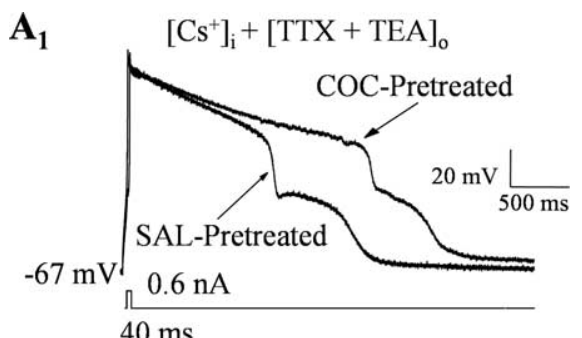

B $_{1} 40 \mathrm{mV}$

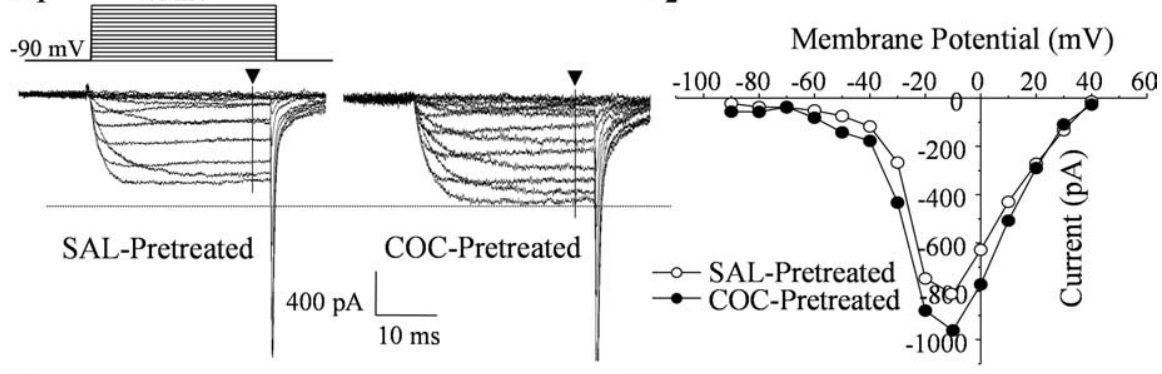

C

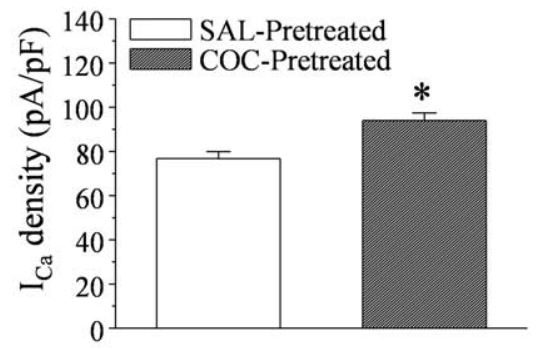

$\mathbf{E}_{1}$

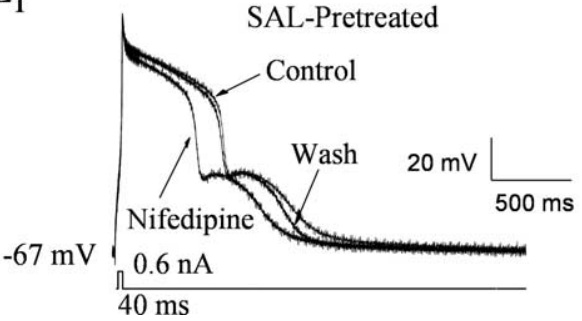

$\mathbf{A}_{2}$

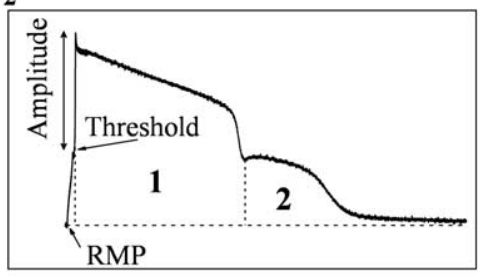

$\mathbf{B}_{2}$

D

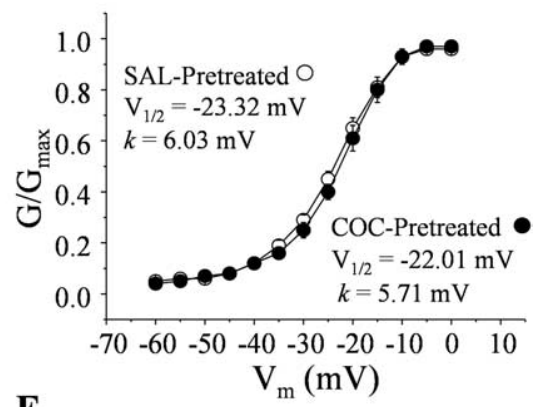

$-67 \mathrm{mV}$

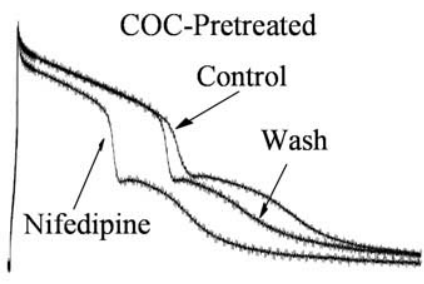

Figure 2. Repeated cocaine administration increased $\mathrm{Ca}^{2+}$ channel function in $\mathrm{mPFC}$ neurons after a $3 \mathrm{~d}$ withdrawal. $A_{1}, B_{1}$, $\boldsymbol{B}_{2}$, Repeated cocaine pretreatment prolonged the duration of $\mathrm{Ca}^{2+}$ plateau potential $\left(\boldsymbol{A}_{\boldsymbol{1}}\right)$ and increased $I_{\mathrm{Ca}}\left(\boldsymbol{B}_{1}, \boldsymbol{B}_{2}\right)$ in $\mathrm{mPFC}$ neurons after a $3 \mathrm{~d}$ withdrawal. $\boldsymbol{B}_{1}$, Triangles indicate the time point at which the $\mathrm{Ca}^{2+}$ currents were measured. $\boldsymbol{A}_{2}$, Two components of an evoked $\mathrm{Ca}^{2+}$ plateau potential (the duration and area under the trace were measured from the threshold to the end of each step, and RMP was used as the baseline of the spike area). C, Repeated cocaine administration significantly increased the $I_{C \text { a }}$ density in dissociated $\mathrm{mPFC}$ neurons $\left({ }^{*} p<0.05\right)$. Error bars reprsent SEM. $\boldsymbol{D}$, There was no significant difference in the activation curve between saline- and cocaine-pretreated neurons. Data represent means $\pm S E M . E_{1}, \boldsymbol{E}_{2}$, Representative traces showing that application of nifedipine (NIF; $5 \mu \mathrm{m}$ ) markedly reduced the duration and area of the first, but not the second, step of $\mathrm{Ca}^{2+}$ plateau potentials in both saline- and cocaine-withdrawn mPFC neurons. The reduced durations and amplitudes of $\mathrm{Ca}^{2+}$ potentials after blockade of L-type $\mathrm{Ca}^{2+}$ channels were comparable in the two groups of neurons $(p>0.05)$. COC, Cocaine; SAL,

Repeated cocaine administration significantly increased the duration and "area" of the primary (first), but not the secondary, component of $\mathrm{Ca}^{2+}$ plateau potentials after a $3 \mathrm{~d}$ withdrawal (Fig. $2 A_{1}$, Table 1). Figure $2 A_{2}$ indicates the characteristics of the two components in a $\mathrm{Ca}^{2+}$ plateau potential and how they were measured. Voltage-clamp recordings in dissociated $\mathrm{mPFC}$ pyramidal neurons revealed that whole-cell $I_{\mathrm{Ca}}$ was enhanced during membrane depolarization after chronic exposure to cocaine (Fig. $2 \mathrm{~B}$ ). Bar graphs show that the density of $I_{\mathrm{Ca}}$ was significantly increased in cocainewithdrawn cells (saline- vs cocaine-pretreated, $76.75 \pm 3.16$ vs 
Table 1. Repeated cocaine administration altered $\mathrm{Ca}^{+2}$ plateau potentials in $\mathrm{mPFC}$ pyramidal neurons after both $3 \mathrm{~d}$ and 2-3 weeks of withdrawal

\begin{tabular}{lcc}
\hline & Saline & \multicolumn{1}{c}{ Cocaine } \\
\hline 3 d of withdrawal & & \\
Number of neurons & 20 & 21 \\
Current to generate $\mathrm{Ca}^{2+}$ spikes (nA) & $0.63 \pm 0.05$ & $0.65 \pm 0.03$ \\
Spike threshold (mV) & $-20.19 \pm 0.67$ & $-20.54 \pm 0.81$ \\
Spike amplitude (mV) & $64.02 \pm 0.96$ & $64.74 \pm 0.93$ \\
Spike duration - one-half amplitude (ms) & $697 \pm 43$ & $808 \pm 26^{*}$ \\
Spike duration, step 1 (ms) & $1349 \pm 125$ & $1938 \pm 131^{*}$ \\
Spike duration, step 2 (ms) & $681 \pm 95$ & $640 \pm 101$ \\
Whole spike duration (ms) & $2002 \pm 147$ & $2578 \pm 89^{*}$ \\
Spike area, step 1 & $110,629 \pm 9616$ & $151,601 \pm 8310^{*}$ \\
Spike area, step 2 & $18,209 \pm 2853$ & $16,855 \pm 3088$ \\
Whole spike area & $126,230 \pm 9946$ & $168,456 \pm 6849^{*}$ \\
2-3 weeks of withdrawal & & \\
Number of neurons & 15 & 12 \\
Current to generate Ca ${ }^{2+}$ spikes (nA) & $0.46 \pm 0.04$ & $0.41 \pm 0.02$ \\
Spike threshold (mV) & $-22.73 \pm 0.75$ & $-23.69 \pm 0.73$ \\
Spike amplitude (mV) & $69.03 \pm 1.27$ & $75.15 \pm 1.05^{*}$ \\
Spike duration - one-half amplitude (ms) & $695 \pm 60$ & $885 \pm 46^{*}$ \\
Spike duration, step 1 (ms) & $1282 \pm 141$ & $1661 \pm 68^{*}$ \\
Spike duration, step 2 (ms) & $664 \pm 50$ & $787 \pm 71$ \\
Whole spike duration (ms) & $1945 \pm 163$ & $2448 \pm 83^{*}$ \\
Spike area, step 1 & $103,047 \pm 11,061$ & $137,542 \pm 5756^{*}$ \\
Spike area, step 2 & $17,084 \pm 1897$ & $20,494 \pm 2405$ \\
Whole spike area & $120,131 \pm 11,640$ & $158,036 \pm 5542^{*}$ \\
\hline
\end{tabular}

The properties of $\mathrm{Ca}^{2+}$ plateau potentials, measured by whole-cell current-clamp recordings, of $\mathrm{mPFC}$ pyramidal neurons from brain slices from saline- and cocaine-pretreated rats are shown. Values represent the mean \pm SEM for the number of neurons indicated $\left({ }^{*} p<0.05\right.$; Student's $t$ test compared with the saline group).

A

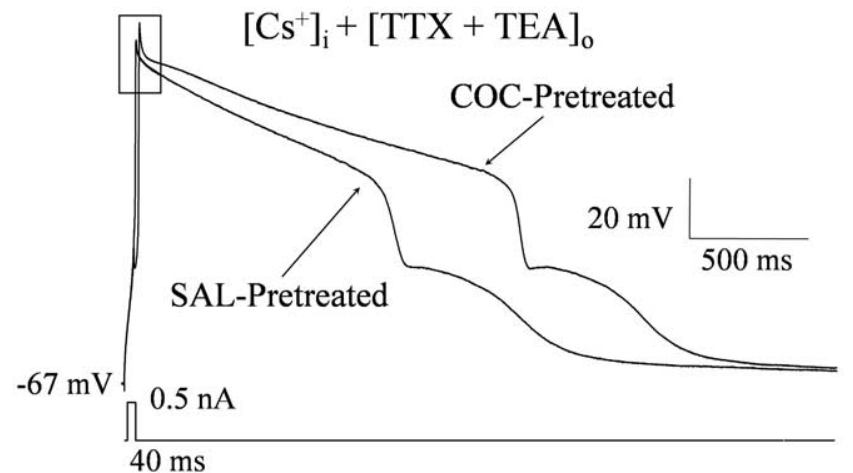

B

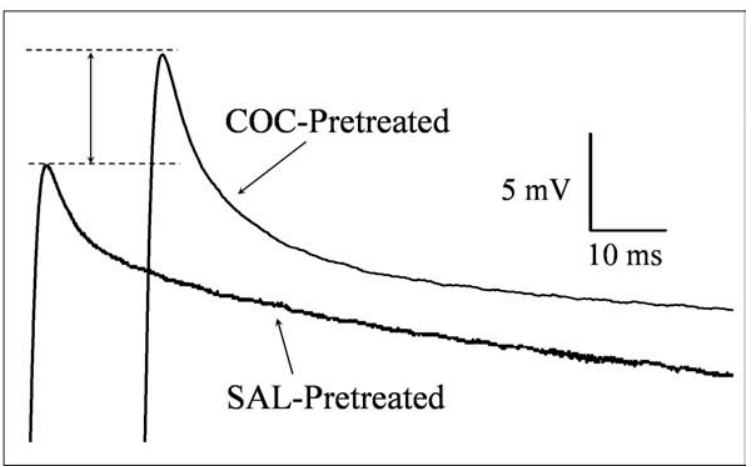

Figure 3. Increased $\mathrm{Ca}^{2+}$ channel function persisted after 2-3 weeks of withdrawal. $A$, Repeated cocaine $(\mathrm{COC})$ administration increased the duration and amplitude of $\mathrm{Ca}^{2+}$ potential in $\mathrm{mPFC}$ neurons after $2-3$ weeks of withdrawal. $\boldsymbol{B}$, Amplification of the boxed area in $\boldsymbol{A}$ to show the increased amplitude. SAL, Saline.
$93.96 \pm 3.48 \mathrm{pA} / \mathrm{pF} ; n=10$ vs 14 cells; $t=$ 3.774; ${ }^{\star} p<0.05$ ) (Fig. $2 C$ ). There was no significant change in the activation curve between saline- and cocaine-pretreated neurons (Fig. $2 D$ ), suggesting that the increased $I_{\mathrm{Ca}}$ might not be attributable to alterations in voltage dependence of activation.

To determine whether L-type $\mathrm{Ca}^{2+}$ channels were functionally involved in the increased duration of $\mathrm{Ca}^{2+}$ plateau potentials, the selective L-type blocker nifedipine was applied in bath during recording. Nifedipine $(5 \mu \mathrm{M} ; \sim 10 \mathrm{~min})$ significantly reduced the duration of evoked $\mathrm{Ca}^{2+}$ plateau potentials in both saline-withdrawn (whole duration, $13.02 \pm 4.20 \%$; whole area, $23.30 \pm 3.44 \% ; n=7$ cells; $p<0.05$; paired $t$ test) and cocaine-withdrawn (whole duration, $27.62 \pm 5.28 \%$; whole area, $37.89 \pm 4.44 \% ; n=8$ cells; $p<0.05$; paired $t$ test) neurons. These changes resulted primarily from the reduction in the first component of the duration and area of $\mathrm{Ca}^{2+}$ potentials in saline-withdrawn (duration, $27.81 \pm 2.69 \%$; area, $29.95 \pm$ $3.11 \% ; n=7$ cells; $p<0.05$; paired $t$ test $)$ (Fig. $2 E_{1}$ ) and cocaine-withdrawn (duration, $43.10 \pm 3.41 \%$; area, $43.62 \pm 3.48 \%$; $n=8$ cells; $p<0.05$; paired $t$ test) neurons (Fig. $2 E_{2}$ ). No significant change was found in the second component of $\mathrm{Ca}^{2+}$ potentials. The nifedipine-induced reduction in the first and whole component of $\mathrm{Ca}^{2+}$ potentials was significantly greater in cocaine-withdrawn mPFC neurons compared with that in the saline group (saline-pretreated vs cocaine-pretreated: whole duration, $13.02 \pm 4.20$ vs $27.62 \pm 5.28 \%$; whole area, $23.30 \pm 3.44$ vs $37.89 \pm 4.44 \% ; n=7$ vs 8 cells; both $p<$ $0.05 ; t$ test). However, there was no significant difference in the duration and area of the first component of $\mathrm{Ca}^{2+}$ potentials between saline- and cocaine-withdrawn neurons after blockade of L-type $\mathrm{Ca}^{2+}$ channels (duration in the saline/nifedipine group vs the cocaine/nifedipine group: $542 \pm 70.00$ vs $658.83 \pm 98.02 \mathrm{~ms}$; area in saline/nifedipine vs cocaine/nifedipine: $42,628 \pm 5265$ vs $522,008 \pm 8144 ; n=7$ vs 8 cells; both $p>0.05 ; t$ test). In addition, the threshold of $\mathrm{Ca}^{2+}$ plateau potentials was significantly increased to more depolarized membrane potential levels after application of nifedipine in both saline- and cocaine-withdrawn $\mathrm{mPFC}$ neurons (saline-pretreated control vs nifedipine, $-22.07 \pm 1.67$ vs $-18.93 \pm 1.80 \mathrm{mV}, n=7$ cells; cocainepretreated control vs nifedipine, $-21.44 \pm 0.97 \mathrm{vs}-18.81 \pm 0.98$ $\mathrm{mV}, n=8$ cells; both $p<0.05$; paired $t$ test). Moreover, the amplitude of the $\mathrm{Ca}^{2+}$ plateau potential was also significantly decreased with blockade of L-type $\mathrm{Ca}^{2+}$ channels in both saline and cocaine groups (saline-pretreated control vs nifedipine, $65.26 \pm 1.91$ vs $56.41 \pm 2.93 \mathrm{mV} ; n=7$ cells; cocaine-pretreated control vs nifedipine, $63.88 \pm 1.48$ vs $53.81 \pm 2.36 \mathrm{mV}, n=8$ cells; both $p<0.05$; paired $t$ test). Similar to that observed in the reduced durations, there was also no significant difference in either the amplitude or the threshold of $\mathrm{Ca}^{2+}$ plateau potentials between saline- and cocaine-withdrawn neurons after selective blockade of L-type $\mathrm{Ca}^{2+}$ potentials (both $p>0.05 ; t$ test).

After 2-3 weeks of withdrawal, the prolonged duration in $\mathrm{Ca}^{2+}$ plateau potentials was still evident in cocaine-withdrawn $\mathrm{mPFC}$ neurons compared with saline-pretreated controls (Fig. 
$3 A$, Table 1). Moreover, a significant increase in the amplitude of the $\mathrm{Ca}^{2+}$ potential also occurred in cocaine-withdrawn neurons (Fig. 3B, Table 1). Technical difficulties restricted us from performing voltage-clamp recording in mPFC neurons of the "aged" rats in either group.

\section{Discussion}

The major finding of this study is that repeated cocaine administration increases the responsiveness of voltage-sensitive $\mathrm{Ca}^{2+}$ channels to membrane depolarization in rat mPFC pyramidal neurons. The prolonged duration of $\mathrm{Ca}^{2+}$ plateau potentials and increased whole-cell $I_{\mathrm{Ca}}$ observed in the present study confirms our previous hypothesis (see Introduction), stating that the increased membrane excitability in cocaine-withdrawn mPFC neurons should be attributed to a facilitation in $I_{\mathrm{Ca}}$ activity, along with a reduction in voltage-gated $\mathrm{K}^{+}$currents.

The increased $I_{\mathrm{Ca}}$ is likely related to the L-type current. It is well known that $I_{\mathrm{Ca}}$ plays an important role in modulating the action potential of $\mathrm{mPFC}$ neurons. In addition to generation of $\mathrm{Ca}^{2+}$ potentials, increased $I_{\mathrm{Ca}}$ activates $\mathrm{Ca}^{2+}$-dependent $\mathrm{K}^{+}$currents, thereby shaping the repolarization, afterhyperpolarization, and frequency adaptation of $\mathrm{Na}^{+}$spikes (Meech, 1978). Although some high-voltage-activated $\mathrm{Ca}^{2+}$ channels (e.g., N- and $\mathrm{P} / \mathrm{Q}$-type) apparently control afterhyperpolarization in cortical neurons (Pineda et al., 1998), L-type channels may regulate the inward currents that modulate the interspike interval during repetitive firing (Pineda et al., 1998). More importantly, recent investigations indicate that repeated cocaine administration increases protein kinase A (PKA) activity in the MPFC (Dong et al., $2005)$, whereas activation of PKA via stimulation of $D_{A} D_{1}$-class receptors enhances a subthreshold L-type $\mathrm{Ca}^{2+}$ potential in PFC pyramidal neurons (Young and Yang, 2004).

Moreover, the present findings also indicate that repeated cocaine administration only enlarged the primary (first), but not the secondary, component of $\mathrm{Ca}^{2+}$ plateau potentials, suggesting that the $\mathrm{Ca}^{2+}$ channels affected by chronic cocaine were probably located within and/or nearby the soma. Previous findings have determined that the stepwise repolarization in $\mathrm{Ca}^{2+}$ potentials should be attributed to the different sites for $\mathrm{Ca}^{2+}$ electrogenesis: the first (primary) component represents $I_{\mathrm{Ca}}$ activated in the soma or dendrites proximal to the soma region, whereas the secondary component reflects $I_{\mathrm{Ca}}$ evoked distally in the dendrites (Reuveni et al., 1993). Because L-type $\mathrm{Ca}^{2+}$ channels are primarily distributed around the soma region (Westenbroek et al., 1990; Hell et al., 1993) and regulate the first component of $\mathrm{Ca}^{2+}$ plateau potentials (Young and Yang, 2004), whereas N- and P/Qtype $\mathrm{Ca}^{2+}$ currents are mainly located in the dendrites (Hillman et al., 1991; Usowicz et al., 1992; Westenbroek et al., 1992; Mills et al., 1994), it is possible that the L-type $I_{\mathrm{Ca}}$ might play a major role in the prolonged duration and increased amplitude of $\mathrm{Ca}^{2+}$ plateau potentials in cocaine-withdrawn $\mathrm{mPFC}$ neurons. In fact, the data obtained from saline- and cocaine-withdrawn MPFC neurons with blockade of L-type $\mathrm{Ca}^{2+}$ channels provide additional evidence in support of our hypothesis. First, nifedipine significantly reduced the first component of the plateau potential without affecting the second component in both saline- and cocainewithdrawn neurons. Second, no significant difference in the duration, the amplitude, or the area of the first components of $\mathrm{Ca}^{2+}$ plateau potentials was found between saline- and cocainewithdrawn neurons after blockade of L-type $\mathrm{Ca}^{2+}$ channels. Therefore, these results, along with the previous ones, clearly indicate that the chronic cocaine-induced facilitation of voltage- sensitive $\mathrm{Ca}^{2+}$ channel function in mPFC pyramidal neurons results from an increased activity of L-type $\mathrm{Ca}^{2+}$ channels.

Nevertheless, although the secondary component of $\mathrm{Ca}^{2+}$ plateau potentials was found to be unaffected, our findings would not rule out any possible changes in the function of $\mathrm{Ca}^{2+}$ and $\mathrm{K}^{+}$ channels located in the dendrites of cocaine-withdrawn pyramidal $\mathrm{mPFC}$ neurons. Investigation using proper recording techniques in the dendrites of those neurons should provide additional information for this issue.

Another interesting finding in this study is that both TEAsensitive and TEA-insensitive VGKCs functionally modulate the generation of $\mathrm{Ca}^{2+}$ potentials in $\mathrm{mPFC}$ neurons of drug-naive rats during membrane depolarization. Our results indicate that blockade of TEA-sensitive $\mathrm{K}^{+}$(and $\mathrm{Na}^{+}$) channels alone was not adequate for evoking $\mathrm{Ca}^{2+}$ plateau potentials with a "full-length" duration in pyramidal mPFC neurons. In contrast, concurrent application of $\mathrm{Cs}^{+}$and TEA, which blocks both TEA-sensitive and TEA-insensitive VGKCs (from the inside and outside of the membrane, respectively) is necessary and critical for the generation of a "full-size" $\mathrm{Ca}^{2+}$ plateau potential. Under this circumstance, typical $\mathrm{Ca}^{2+}$ plateau potentials could be reliably and constantly evoked by depolarizing current pulses in every cell recorded. This result is in agreement with our previous finding in medium spiny neurons within the rat nucleus accumbens (NAc) (Hu et al., 2004), suggesting a general character of evoked $\mathrm{Ca}^{2+}$ potentials, which explains why various $\mathrm{Ca}^{2+}$ spikes may be generated with different potential forms in neurons in response to membrane depolarization. In addition, this finding also reveals the role of VGKCs in "fine tuning" the function of voltagesensitive $\mathrm{Ca}^{2+}$ channels in pyramidal mPFC neurons.

The present study provides novel evidence indicating that chronic cocaine treatment induces an enduring facilitation in $I_{\mathrm{Ca}}$ in rat $\mathrm{mPFC}$ neurons in response to excitatory stimuli. This change in $\mathrm{Ca}^{2+}$ entry, which occurs after increased activity of L-type $I_{\mathrm{Ca}}$, and a resulting increase in the membrane excitability, could be translated to an enhanced glutamatergic output to the ventral tegmental area and NAc (Smith et al., 1995; Reid et al., 1997), particularly in cocaine-sensitized rats (Pierce et al., 1996; Kalivas and Duffy, 1998) when they are challenged with the same drug after a short-term withdrawal (Williams and Steketee, 2004). More importantly, the alterations in $\mathrm{Ca}^{2+}$ channel function appeared to be enduring, because they persisted for at least 2-3 weeks after the termination of chronic cocaine administration. These findings suggest that, although the basal neuronal activity within the withdrawn mPFC significantly decreases after chronic exposure to cocaine, such as that shown in functional image study (for review, see Volkow et al., 2004), the responsiveness of pyramidal mPFC neurons to certain stimuli including, but not limited to, environmental cues or an additional (challenge) dose of psychostimulants, may be markedly increased. Therefore, these changes in $\mathrm{Ca}^{2+}$ and DA signaling within the mesocortical and mesoaccumbens DA systems may ultimately contribute to the development of behavioral sensitization and the withdrawal effects of chronic cocaine.

\section{References}

Brown AM, Schwindt PC, Crill WE (1993) Voltage dependence and activation kinetics of pharmacologically defined components of the highthreshold calcium current in rat neocortical neurons. J Neurophysiol 70:1530-1543.

Dong Y, Nasif F, Tsui JJ, Ju WI, Cooper DC, Hu XT, Malenka RC, White FJ (2005) Cocaine-induced plasticity of intrinsic membrane properties in prefrontal cortex pyramidal neurons: adaptations in potassium currents. J Neurosci 25:936-940. 
Hell JW, Westenbroek RE, Warner C, Ahlijanian MK, Prystay W, Gilbert MM, Snutch TP, Catterall WA (1993) Identification and differential subcellular localization of the neuronal class C and class D L-type calcium channel alpha 1 subunits. J Cell Biol 123:949-962.

Hille B (2001) Ion channels of excitable membranes, Chap 1-5. Sunderland, MA: Sinauer.

Hillman D, Chen S, Aung TT, Cherksey B, Sugimori M, Llinas RR (1991) Localization of P-type calcium channels in the central nervous system. Proc Natl Acad Sci USA 88:7076-7080.

Hu XT, Basu S, White FJ (2004) Repeated cocaine administration suppresses $\mathrm{HVA}-\mathrm{Ca}^{2+}$ potentials and enhances activity of $\mathrm{K}+$ channels in rat nucleus accumbens neurons. J Neurophysiol 92:1597-1607.

Kalivas PW, Duffy P (1998) Repeated cocaine administration alters extracellular glutamate in the ventral tegmental area. J Neurochem 70:1497-1502.

Li Y, Hu XT, Berney TG, Vartanian AJ, Stine CD, Wolf ME, White FJ (1999) Both glutamate receptor antagonists and prefrontal cortex lesions prevent induction of cocaine sensitization and associated neuroadaptations. Synapse 34:169-180.

Lorenzon NM, Foehring RC (1995) Characterization of pharmacologically identified voltage-gated calcium channel currents in acutely isolated rat neocortical neurons. I. Adult neurons. J Neurophysiol 73:1430-1442.

Meech RW (1978) Calcium-dependent potassium activation in nervous tissues. Annu Rev Biophys Bioeng 7:1-18.

Mills LR, Niesen CE, So AP, Carlen PL, Spigelman I, Jones OT (1994) $\mathrm{N}$-type $\mathrm{Ca}^{2+}$ channels are located on somata, dendrites, and a subpopulation of dendritic spines on live hippocampal pyramidal neurons. J Neurosci 14:6815-6824.

Nasif FJ, Sidiropoulou K, Hu XT, White FJ (2005) Repeated cocaine administration increases membrane excitability of pyramidal neurons in the rat medial prefrontal cortex. J Pharmacol Exp Ther 312:1305-1313.

Pierce RC, Bell K, Duffy P, Kalivas PW (1996) Repeated cocaine augments excitatory amino acid transmission in the nucleus accumbens only in rats having developed behavioral sensitization. J Neurosci 16:1550-1560.

Pierce RC, Reeder DC, Hicks J, Morgan ZR, Kalivas PW (1998) Ibotenic acid lesions of the dorsal prefrontal cortex disrupt the expression of behavioral sensitization to cocaine. Neuroscience 82:1103-1114.

Pineda JC, Waters RS, Foehring RC (1998) Specificity in the interaction of HVA Ca ${ }^{2+}$ channel types with $\mathrm{Ca}^{2+}$-dependent AHPs and firing behavior in neocortical pyramidal neurons. J Neurophysiol 79:2522-2534.

Reid MS, Hsu Jr K, Berger SP (1997) Cocaine and amphetamine preferen- tially stimulate glutamate release in the limbic system: studies on the involvement of dopamine. Synapse 27:95-105.

Reuveni I, Friedman A, Amitai Y, Gutnick MJ (1993) Stepwise repolarization from $\mathrm{Ca}^{2+}$ plateaus in neocortical pyramidal cells: evidence for nonhomogeneous distribution of $\mathrm{HVA} \mathrm{Ca}^{2+}$ channels in dendrites. J Neurosci 13:4609-4621.

Smith JA, Mo Q, Guo H, Kunko PM, Robinson SE (1995) Cocaine increases extraneuronal levels of aspartate and glutamate in the nucleus accumbens. Brain Res 683:264-269.

Stuart GJ, Dodt HU, Sakmann B (1993) Patch-clamp recordings from the soma and dendrites of neurons in brain slices using infrared video microscopy. Pflügers Arch 423:511-518.

Tzschentke TM (2001) Pharmacology and behavioral pharmacology of the mesocortical dopamine system. Prog Neurobiol 63:241-320.

Usowicz MM, Sugimori M, Cherksey B, Llinas R (1992) P-type calcium channels in the somata and dendrites of adult cerebellar Purkinje cells. Neuron 9:1185-1199.

Volkow ND, Fowler JS, Wang GJ (2004) The addicted human brain viewed in the light of imaging studies: brain circuits and treatment strategies. Neuropharmacology 47 [Suppl 1]:3-13.

Westenbroek RE, Ahlijanian MK, Catterall WA (1990) Clustering of L-type $\mathrm{Ca}^{2+}$ channels at the base of major dendrites in hippocampal pyramidal neurons. Nature 347:281-284.

Westenbroek RE, Hell JW, Warner C, Dubel SJ, Snutch TP, Catterall WA (1992) Biochemical properties and subcellular distribution of an N-type calcium channel alpha 1 subunit. Neuron 9:1099-1115.

Williams JM, Steketee JD (2004) Cocaine increases medial prefrontal cortical glutamate overflow in cocaine-sensitized rats: a time course study. Eur J Neurosci 20:1639-1646.

Wolf ME (1998) The role of excitatory amino acids in behavioral sensitization to psychomotor stimulants. Prog Neurobiol 54:679-720.

Ye JH, Akaike N (1993) Calcium currents in pyramidal neurons acutely dissociated from the rat frontal cortex: a study by the nystatin perforated patch technique. Brain Res 606:111-117.

Young CE, Yang CR (2004) Dopamine $\mathrm{D}_{1} / \mathrm{D}_{5}$ receptor modulates statedependent switching of soma-dendritic $\mathrm{Ca}^{2+}$ potentials via differential protein kinase $\mathrm{A}$ and $\mathrm{C}$ activation in rat prefrontal cortical neurons. J Neurosci 24:8-23.

Zhang XF, Cooper DC, White FJ (2002) Repeated cocaine treatment decreases whole-cell calcium current in rat nucleus accumbens neurons. J Pharmacol Exp Ther 301:1119-1125. 